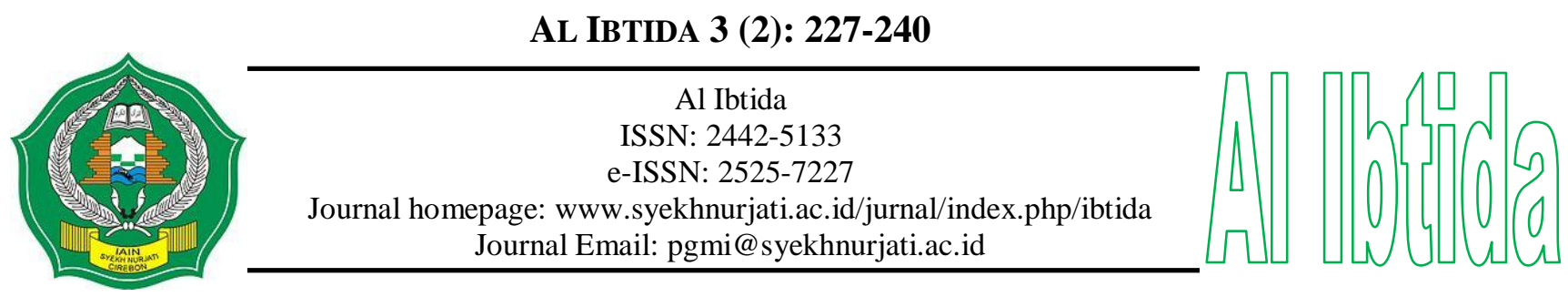

\title{
PARADIGMA INTEGRATIF DALAM PEMBELAJARAN IPA MI
}

\author{
Irham Nugroho* \\ *Jurusan Pendidikan Guru MI, FAI, UM Magelang \\ email:irham_nugroho@ymail.com
}

\begin{abstract}
Abstrak
Ilmu pengetahuan secara hakiki bersumber dari Allah SWT yang diturunkan lewat wahyu kepada Nabi Muhammad SAW yang diwujudkan dalam Al Qur'an. Paradigma merupakan kumpulan tata nilai yang membentuk pola pikir seseorang sebagai titik tolak pandangannya sehingga akan membentuk citra subjektif seseorang - mengenai realita - dan akhirnya akan menentukan bagaimana seseorang menanggapi realita itu. Manusia tidak seharusnya pernah berhenti berfikir mengenai dirinya, alam sekitarnya, dan (yang terpenting) Sang Penciptanya. Islam mengajarkan kepada pemeluknya untuk senantiasa mengadakan pengkajian terhadap setiap prilaku atau bentuk perputaran dan perubahan yang terjadi, baik pada gejala di alam semesta ataupun yang terjadi diantara sesama manusia. Pembelajaran IPA di Madrasah Ibtidaiyah seharusnya menanamkan nilai-nilai moral yang dapat mendidik peserta didik menjadi berkarakter, hal tersebut dapat dilakukan salah satunya dengan memberikan pembelajaran IPA menggunakan pendekatan integrasi bayani, burhani, dan irfani.
\end{abstract}

Keyword: Pembelajaran IPA, Pendekatan integrasi bayani, burhani, dan irfani

\begin{abstract}
Knowledge is intrinsically comes from Allah SWT which is revealed to Prophet Muhammad SAW and is embodied in Al Qur'an. Paradigm is a group of values which form one's thought as his or her starting point of view so that it will form one's subjective image - about a reality - which finally will determine how this one responds the reality. Human should not ever stop thinking about him/her self, his/her surrounding, and (the most important) The Creator. Islam taught its followers to always undertake studies on behavior or any rotation and changes happen, either on natural phenomenon or what happen amongst human beings. Science teaching in Madrasah Ibtidaiyah (Islamic Elementary School) should instill moral values that educate students to become
\end{abstract}


caracterized. It can be undertaken by science teaching using integrated bayani, burhani, and irfani approach.

Keyword: science teaching, integrated bayani burhani irfani approach.

\section{PENDAHULUAN}

Seorang muslim tidak dibenarkan hidup dalam keadaan putus hubungan dengan ilmu. Seperti juga dalam Sabda Nabi Muhammad SAW: yang tidak berkesempatan menjadi orang yang berilmu hendaknya selalu ia belajar (menuntut ilmu), yang tidak berkesempatan belajar hendaknya ia berupaya menjadi mustami (pendengar setia), atau kalau tidak hendaknya ia menjadi pecinta ilmu dan pecinta orang yang berilmu; tetapi, jangan sampai ia menjadi pembenci ilmu dan pembenci orang yang berilmu karena ia pasti celaka/binasa (Amin Abdullah, 2003 : 99).

Islam mengajarkan kepada pemeluknya untuk senantiasa mengadakan pengkajian terhadap setiap prilaku atau bentuk perputaran dan perubahan yang terjadi, baik pada gejala di alam semesta ataupun yang terjadi diantara sesama manusia. Kaitannya dengan ini, bahwa Islam menekankan eksplorasi keilmuan, sebagaimana sabda Nabi Muhammad SAW, menuntut ilmu adalah wajib bagi orang Islam (Sahirul Alim, 1996: 5). Ilmu, dalam hal ini ekplorasi sains dan teknologi, khususnya ilmu-ilmu empiris, de facto, telah mengalami kemajuan yang begitu mengagumkan, baik dilihat dari segi kronologi waktu ataupun hasilhasil penemuan baru yang berhasil diraih. Persoalannya adalah bahwa tidak semua manusia menguasai, mengalami dan menikmati perkembangan serta hasil-hasil dari eksplorasi sains dan teknologi itu (Sahirul Alim, 1996: 5).

Memang manusia tidak seharusnya pernah berhenti berfikir mengenai dirinya, alam sekitarnya, dan (yang terpenting) Sang Penciptanya. Dilihat dari sudut pandang memulai aktifitas pemikiran tadi maka dikenal 3 (tiga) kubu pemikiran utama, yaitu:

1) Kubu agama, yang memulai dengan membuka tabir burhan qur'ani dan sunni.

2) Kubu umum, yang memulainya dengan berpegangan pada burhan insani dan alami.

3) Kubu islami, yang berfikir secara terpadu yaitu melalui pendekatan burhan qur'ani, sunni dan kauni secara simultan dan utuh (komperhensif); artinya tidak secara sempalan-sempalan.

Dari penjelasan di atas menerangkan tentang tiga sudut pandang untuk memulai pemikiran. Dalam hal ini penulis akan mengerucutkan paradigma integratif dalam biologi dengan pembahasan bayani, burhani, dan irfani. Biologi merupakan salah satu cabang ilmu 
yang berhubungan dengan sains. Kata ilmu pengetahuan atau 'sains' dalam bahasa Indonesia mempunyai beberapa pandangan kata dalam bahasa asing antara lain; science (dalam bahasa Inggris), wissenschaft (Jerman) atau wetenschap (Belanda). Sedangkan yang dimaksud dengan pengertian science, tanpa adanya keterangan lebih lanjut, adalah natural science atau 'ilmu-ilmu kealaman'. Natural sciences merupakan ilmu-ilmu yang mempelajari fenomena-fenomena alam semesta dengan segala isinya, yang termasuk ke dalam natural science (selanjutnya disebut science) adalah 'ilmu-ilmu dasar' (basic science), disebut pula sebagai ilmu-ilmu murni (pure science), seperti biologi, kimia, fisika, dan astronomi, dengan segala cabangnya. Derivasi dari basic sciences adalah applied sciences atau ilmu-ilmu terapan', yaitu farmasi, kedokteran, pertanian, kedokteran gigi, optometri, dan lain-lain (Amin Abdullah, 2003: 106).

Biologi adalah ilmu yang mempelajari tentang mahluk hidup, baik itu tumbuhan atau hewan. Biologi dibagi menjadi beberapa kelas, diantaranya Zoologi, Botani, Mikrobiologi, dan Virologi. Menurut Baiquni, definisi ilmu pengetahuan atau sains adalah "himpunan pengetahuan manusia tentang alam yang disimpulkan secara rasional dari hasilhasil analisis kritis terhadap data-data pengukuran yang diperoleh melalui observasi pada fenomena-fenomena alam (Amin Abdullah, 2003: 107). Paradigma Secara etimologis berasal dari bahasa inggris paradigm yang berarti type of something, model, pattern (bentuk/tipe, model, pola) dan secara terminologis adalah a total view of problem, a total outlook, not just a problem in isolation (cara berpikir atau sketsa pandang menyeluruh yang mendasari rancang bangun suatu sistem keilmuan) (Ismail SM, $2001: 8$ ).

Paradigma adalah kumpulan tata nilai yang membentuk pola pikir seseorang sebagai titik tolak pandangannya sehingga akan membentuk citra subjektif seseorang - mengenai realita - dan akhirnya akan menentukan bagaimana seseorang menanggapi realita itu. Menurut Thomas Samuel Kuhn, paradigma adalah cara meninjau benda-benda, asumsi yang dipakai bersama yang mengatur pandangan dari suatu zaman dan pendekatannya atas masalah-masalah ilmiah. Istilah paradigma dalam arti teknis tersebut bertalian dengan filsafat ilmu. Kemudian istilah disciplinary matrix dipakai lebih mendekati arti diatas, dan paradigma menjadi bentuk-bentuk yang baku bagi pemecahan masalah.

Kemudian pemecahan-pemecahan ini dipakai untuk memecahkan masalah selanjutnya dan dengan demikian mengatur bentuk-bentuk pemecahan lebih lanjut. Pergeseran paradigma terjadi sebagaimana perkembangan ilmu kebanyakan, paradigma tidak dapat didefinisikan tetapi merupakan cita-cita konseptual yang memberitahu dan mengilhami suatu pemikiran dari suatu masyarakat tertentu mengarahkan perhatian- 
perhatiannya dan menentukan macam kesadaran yang kuat akan bentuk objektivitas bagi masyarakat tertentu (Amin Abdullah, 2003: 92). Berdasarkan uraian diatas, maka penulis beranggapan penting untuk mengkaji paradigma integratif dalam biologi ditinjau dari bayani, burhani, dan irfani.

\section{PEMBAHASAN}

Kata biologi berasal dari bahasa Yunani life discourse (wacana kehidupan) yang diintroduser pertama tahun 1800 oleh beberapa pedagang untuk menunjukkan the science of life, ilmu tentang kehidupan, atau everything that pertainsof living bodies (segala sesuatu yang berhubungan dengan makhluk hidup). Dengan demikin, terma biologi sebelumnya muncul pada era klasik. Ilmu ini bahkan terkait dengan disiplin keilmuan yang sekarang disebut kedokteran, farmasi, dan kimia. Untuk itu, Ilmuan muslim yang termasuk ahli dalam biologi, dia secara otomatis ahli dalam kedokteran.

Apa yang disebut biologi atau ilmu tentang kehidupan berasal dari hasil penelitian dari berbagai disiplin, yaitu obat-obatan, pembedahan, perdukunan anak, farmasi, pertanian, kehutanan, berburu, perikanan, perkembangbiakan, eksplorasi, praktik [dokter] kehewanan, pemeliharaan dan industri makanan, bioteknologi, dan pemeliharaan lingkungan. Cakupan ilmu biologi adalah tentang perkembangan dan diferensiasi makhluk hidup, sitologi, genetika, biologi molkuler, evolusi, dan ekologi (Muqowim, 2012: 237).

Dengan demikian, untuk memahami sains biologi dalam Islam tidak dapat dilepaskan dari konteks locus dan tempus ketika itu. Sains Islam tidak muncul begitu saja, namun dipengaruhi sains sebelum Islam. Hanya saja sains yang dibangun oleh ilmuan muslim ini mempunyai keunikan karena tidak lepas dari spiritualitas ajaran Islam yang bersumber dari al-Qur'an dan al-Sunnah (Muqowim, 2012: 239).

\section{A. Bayani}

Secara etimologi, istilah bayani terdapat empat pengertian; perbedaan, berbeda, jelas, penjelas. Kalau disusun secara hirarkis atas dasar pemilihan metode dan visi maka dapat dikatakan bahwa bayani sebagai metode berarti "perbedaan dalam penjelasan", sedangkan bayani sebagi visi berarti "berbeda dan jelas" (Nasyaria Siregar, 2013: 5). Dalam hal ini penulis meninjau dari sisi bayani biologi, dengan pengerucutan tentang: "pemanfaatan tumbuhan oleh manusia dan dampaknya".

Manusia memiliki banyak kelebihan dan keunggulan jika dibandingkan dengan makhluk lain, karena itu manusia sangat berperan dalam menentukan kualitas lingkungan. Lingkungan menjadi baik atau sebaliknya sangat tergantung dengan prilaku 
manusia. Sehingga diperlukan manusia yang sadar akan lingkungan yaitu manusia yang memahami dan menerapkan etika lingkungan. Etika lingkungan merupakan tata cara memperlakukan lingkungan sesuai konsep ekologi (Ahmad Abtokhi, 2008: 275).

Semua prinsip tentang ekologi tentunya kembali pada SDM (sumber daya manusia) yang mengelolanya. Semua yang ada di alam dapat dimanfaatkan semaksimal mungkin oleh semua makhluk hidup yang ada di bumi ini, namun hal itu tentunya dengan batasan-batasan yang telah ditentukan menurut takarannya. Meskipun demikian masih banyak manusia yang belum menerapkan sistem ekologi, misalnya manusia masih menebang pohon di hutan secara liar tanpa melakukan reboisasi, sehingga dapat mengancam kelestarian hutan dan merusak lingkungan.

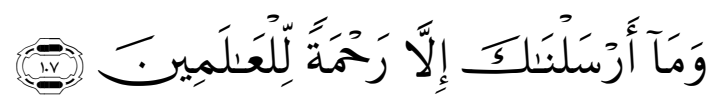

"dan Tiadalah Kami mengutus kamu, melainkan untuk (menjadi) rahmat bagi semesta alam”. (al-Anbiyaa: 107)

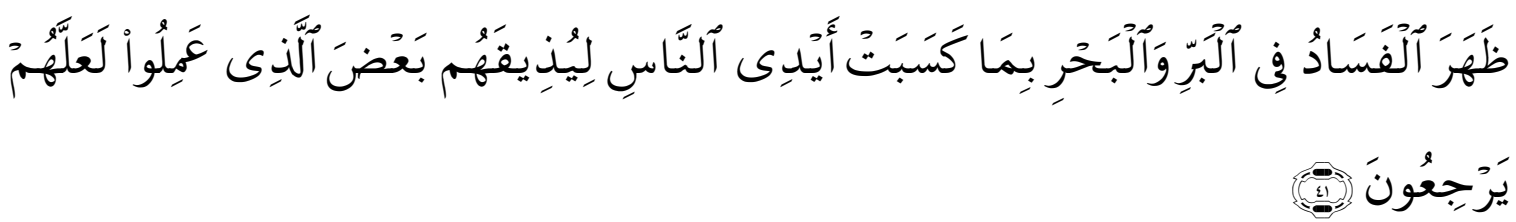

"telah nampak kerusakan di darat dan di laut disebabkan karena perbuatan tangan manusia, supaya Allah merasakan kepada mereka sebahagian dari (akibat) perbuatan mereka, agar mereka kembali (ke jalan yang benar)".(al-Rum:41)

Kedua ayat di atas memberikan gambaran sesuatu yang kontradiktif antara harapan Allah SWT dengan apa yang dilakukan oleh manusia. Manusia yang diharapkan menjadi rahmat bagi seluruh alam, sebagai pemimpin (khalifah) di muka bumi dengan segala kemampuannya terkadang tidak menyadari, bahkan melupakannya, mereka menuruti hawa nafsunya. Berikut ini beberapa hal yang berkaitan dengan hal tersebut, dengan harapan kita dapat menyadari dampak negatif sebagai akibat kegiatan itu (Ahmad Abtokhi, 2008: 277).

Kehidupan manusia tidak dapat lepas dari ketergantungan terhadap tumbuhan. Ketergantungan tersebut baik dalam makanan, pakaian maupun perumahan. Manusia memerlukan kayu untuk perabot rumah tangga, sepeti meja, kursi, dan almari, dalam rangka memenuhi kebutuhan kayu itulah manusia menebang pohon, kemudian batang pohon diolah menjadi kaso, papan, dan balok. Tetapi penebangan pepohonan di hutan 
secara liar dan tidak dilakukan reboisasi dapat mengancam kelestarian hutan dan merusak lingkungan.

\section{B. Burhani}

Al-Burhan dalam bahasa Arab berarti al-hujjah fasillah al-bayyinah (bukti pemutusan yang jelas) yang dalam bahasa inggris disebut demonstration yang berasal dari bahasa latin demonstratio yang artinya isyarat, sifat dan keterangan sesuatu yang menampakkan. Dalam prespektif logika, al-burhan adalah aktifitas berpikir yang menetapkan kebenaran sesuatu melalui metode penalaran yang mengaitkan pengetahuan dan bukti-buktinya mendahului kebenaran, sedangkan dalam pengertian umum alburhan berarti aktifitas berpikir untuk menentukan kebenaran sesuatu (Nasyaria Siregar, 2013: 6). Dalam hal ini pandangan integratif dalam biologi, penulis mengambil contoh tumbuhan yang ada di sekitar kita yaitu tentang pohon jati.

Hutan memiliki fungsi ekologis yang penting, antara lain pengaturan suhu lingkungan, pengaturan kelembaban, pengatur candangan air, penyedia oksigen, mencegah erosi, menghambat angin, tempat berlindung, dan berkembangbiaknya berbagai satwa, penghasil buah dan kayu. Selain itu hutan berperan sebagai paru-paru bumi yang mempengaruhi iklim dunia (global). Jika hutan rusak, maka kadar $\mathrm{CO}^{2}$ mengikat sehingga suhu bumi semakin panas. Akibatnya terjadi perubahan iklim global, badai topan, banjir dan bencana alam (Ahmad Abtokhi, 2008: 227).

Dari keterangan surat al-Anbiya ayat 107 dan surat al-Rum ayat 41 menjelaskan tentang nampaknya kerusakan alam semesta ini dipengaruhi oleh beberapa faktor. Salah satu faktornya adalah manusia (khalifah) yang ada di bumi ini. Ada beberapa tumbuhan di bumi ini yang mempunyai manfaat untuk semua alam. Salah satu contoh tumbuhan yang terdapat di lingkungan sekitar adalah tumbuhan jati. Tumbuhan jati atau pohon jati adalah pohon yang dapat tumbuh dengan baik di Indonesia. Tumbuhan jati memiliki beberapa manfaat, diantaranya dapat dimanfaatkan untuk kusen, pintu, meja, kursi, almari dan lain sebagainya. Dalam pemanfaatan sumber daya alam seperti tumbuhan jati nampaknya kurang terkontrol sehingga antara penanaman dan penebangan tidak sepadan. Sehingga menimbulkan beberapa masalah alam yang mengakibatkan bencana alam seperti tanah longsor, banjir, serta yang sedang gencar terdengar di telinga masyarakat yaitu global warming. 
Hutan di Indonesia kian menyempit, karena banyak penebang hutan dengan tujuan ekonomis tanpa mempertimbangkan dampak ekologisnya. Dampak negatif dari penebangan hutan antara lain:

a) Di musim hujan terjadi banjir dan lapisan tanah subur terkikis terbawa air (erosi).

b) Struktur tanah menjadi labil sehingga mudah longsor.

c) Persedian air tanah berkurang.

d) Persedian oksigen berkurang.

e) Kadar $\mathrm{CO}^{2}$ meningkat.

f) Di musim kemarau, sungai dan mata air mengering, suhu lingkungan meningkat sehingga mudah pula terjadi kebakaran.

g) Punahnya berbagai sepesies hewan, tumbuhan dan mikroorganisme di dalam hutan.

Pembalakan kayu secara liar (illegal loging), yang sekarang ini marak terjadi hampir di seluruh hutan di Indonesia, sungguh sangat disayangkan. Selain merugikan negara, pencurian kayu seperti ini juga sangat merugikan dari segi ekologi. Ironisnya, kejadian ini tidak hanya terjadi di hutan darat saja, melainkan juga menimpa hutan di wilayah pesisir pantai, disebut dengan hutan mangrove. Hutan mangrove sebagai salah satu ekosistem terpenting di daerah peralihan antara darat dan laut, yang keberadaannya mempunyai banyak manfaat, baik ekonomis, fisik dan ekologis, kini semakin menipis akibat ditebangi oleh oknum masyarakat yang tak tahu arti pentingnya ekosistem ini (Ahmad Abtokhi, 2008: 278).

\section{Irfani}

Irfani diambil dari kata irfan yang menurut bahasa berasal dari kata arafa (mengerti, mengetahui). Kata irfan searti dengan kata ma'rifah yang terkenal dikalangan ahli tasawuf yakni pengertian yang mendalam pada hati dalam bentuk ilham atau sesuatu yang dapat membuka tabir yang menutup hati. Perbedaan bayani dan irfani adalah bahwa pengetahuan bayani didapat dengan jalan khabar yang terdiri dari nash alQur'an dan Sunnah yang pemahamannya dengan pemikiran (ijtihad), sedangkan irfani ialah pengetahuan yang dicapai dengan cara mencari ilham, kasyf (terbuka hatinya), i’yah (persepsi langsung) dan isyraq (Nasyaria Siregar, 2013: 7).

Dalam hal ini pandangan integrative dalam biologi yang membahas tentang tumbuhan mengemukakan nilai-nilai yang terkandung di dalamnya yaitu: pohon jati merupakan salah satu pohon yang mempunyai manfaat dari daun batang sampai akarnya, sehingga pohon jati merupakan salah satu pohon yang menjadi primadona di Indonesia. Daun jati dimanfaatkan secara tradisional di Jawa sebagai pembungkus 
makanan. Nasi yang dibungkus dengan daun jati terasa lebih nikmat (Ahmad Abtokhi, 2008: 283). Masyarakat Jawa Timur, Pulau Bawean menyeduh daun jati untuk menghasilkan pewarna coklat merah alami. Masyarakat Lamongan memilih menyeduh tumbukan daun mudanya. Sementara itu masyarakat Pulau Madura mencampurkan tumbukan daun jati dengan asam jawa. Pada masa itu pengidap penyakit kolera pun dianjurkan untuk meminum seduhan kayu dan daun jati yang pahit sebagai penawar sakit. Manusia memanfaatkan kayu untuk dibuat perabot rumah tangga, sepeti meja, kursi, dan almari, juga untuk dibuat rumah, seperti kusen, jendela, pintu juga untuk kerangka rumah. Pada abad ke-17, tercatat jika masyarakat Sulawesi Selatan menggunakan akar jati sebagai penghasil pewarna kuning dan kuning cokelat alami untuk bahan anyaman.

Allah menciptakan segala yang ada di muka bumi ini bukan tanpa rencana. Sungguh bila kita sebagai manusia mau dan terus berusaha maka Allah akan membuka cakrawala pengetahuan untuk manusia. Bila kita renungi bersama, kita bisa mengambil hikmah dari pohon jati, yaitu bagaimana kita berusaha semaksimal mungkin menjadi makhluk hidup, manusia, khalifah di muka bumi ini yang dapat mempunyai dampak dan bermanfaat bagi lingkungan sekitar.

\section{Contoh Pembelajaran Sains di Madrasah Ibtidaiyah}

Sebelum melakukan pembelajaran sains di Madrasah Ibtidaiyah seharusnya guru menyiapkan rencana pelaksanaan pembelajaran dan bahan ajar yang berfungsi sebagai acuan pembelajaran sehingga penyampaian materi pelajaran kepada peserta didik dapat berjalan secara maksimal. Berikut ini contoh RPP dan bahan ajar dalam pembelajaran sains di kelas VI MI/SD.

\begin{tabular}{|c|c|}
\hline RENCANA PEI & $\begin{array}{l}\text { ANAAN PEMBELAJARAN } \\
\text { ( RPP ) }\end{array}$ \\
\hline Sekolah & $: \ldots \ldots \ldots \ldots$ \\
\hline Mata Pelajaran & : Ilmu Pengetahuan Alam ( IPA ) \\
\hline Kelas/Semester & : VI / 1 \\
\hline Materi Pokok & : Keseimbangan Ekosistem \\
\hline Waktu & : 4 x 35 menit \\
\hline Metode & : Ceramah dan diskusi \\
\hline
\end{tabular}

A. Standar Kompetensi

3. Memahami pengaruh kegiatan manusia terhadap keseimbangan lingkungan

B. Kompetensi Dasar

3.1 Mengidentifikasi kegiatan manusia yang dapat mempengaruhi keseimbangan alam (ekosistem) 
C. Tujuan Pembelajaran:

1. Siswa dapat memahami peta konsep tentang keseimbangan ekosistem.

2. Siswa dapat Menyebutkan kegiatan manusia yang dapat mempengaruhi keseimbangan ekosistem.

3. Siswa dapat menjelaskan dampak dari kegiatan manusia yang mempengaruhi keseimbangan ekosistem

4. Siswa berdiskusi mengenai kegiatan manusia yang dapat mempengaruhi keseimbangan ekosistem.

D. Karakter siswa yang diharapkan :

Disiplin (discipline), Rasa hormat dan perhatian (respect), Tekun (diligence), Tanggung jawab (responsibility) dan Ketelitian (carefulness).

E. Materi Essensial

Berbagai kegiatan manusia yang dapat mempengaruhi keseimbangan ekosistem.

F. Media Belajar

Buku SAINS SD Relevan Kelas VI

G. Rincian Kegiatan Pembelajaran Siswa

1. Pendahuluan

Apersepsi dan Motivasi:

(10 menit)

Menyampaikan tujuan pembelajaran dan kompetensi yang diharapkan

2. Kegiatan Inti

Eksplorasi

(100 menit)

Dalam kegiatan eksplorasi, guru:

a. Siswa dapat Memahami peta konsep tentang keseimbangan ekosistem

b. Menjelaskan dampak dari kegiatan manusia yang mempengaruhi keseimbangan ekosistem

c. Penyatuan sel telur dan sel sperma $\rightarrow$ pembuahan $\rightarrow$ embrio $\rightarrow$ perkembangan bayi dalam rahim $\rightarrow$ bayi

d. Mengetahui calon bayi memperoleh makan

e. Melibatkan peserta didik secara aktif dalam setiap kegiatan pembelajaran; dan

f. Memfasilitasi peserta didik melakukan percobaan di laboratorium, studio, atau lapangan.

\section{Elaborasi}

Dalam kegiatan elaborasi, guru:

a. Menyebutkan kegiatan manusia yang dapat mempengaruhi keseimbangan ekosistem.

Penebangan dan pembakaran hutan

Penggunaan pupuk dan pestisida secara berlebihan

Perburuan liar

Perusakan terumbu karang

Pembangunan industri (pabrik) 


\begin{tabular}{|l}
\hline b. Siswa berdiskusi mengenai kegiatan manusia yang dapat \\
mempengaruhi keseimbangan ekosistem \\
c. memfasilitasi peserta didik melalui pemberian tugas, \\
diskusi, dan lain-lain untuk memunculkan gagasan baru \\
baik secara lisan maupun tertulis; \\
d. memberi kesempatan untuk berpikir, menganalisis, \\
menyelesaikan masalah, dan bertindak tanpa rasa takut; \\
e. memfasilitasi peserta didik membuat laporan eksplorasi \\
$\quad$ yang dilakukan baik lisan maupun tertulis, secara \\
individual maupun kelompok; \\
f. memfasilitasi peserta didik untuk menyajikan hasil kerja \\
individual maupun kelompok; \\
Konfirmasi \\
Dalam kegiatan konfirmasi, guru: \\
a. Guru bertanya jawab tentang hal-hal yang belum \\
diketahui siswa \\
b. Guru bersama siswa bertanya jawab meluruskan \\
kesalahan pemahaman, memberikan penguatan dan \\
penyimpulan
\end{tabular}

H. Penilaian

\begin{tabular}{|c|c|c|c|}
\hline $\begin{array}{c}\text { Indikator Pencapaian } \\
\text { Kompetensi }\end{array}$ & $\begin{array}{c}\text { Teknik } \\
\text { Penilaian }\end{array}$ & $\begin{array}{c}\text { Bentuk } \\
\text { Instrumen }\end{array}$ & Instrumen/ Soal \\
\hline $\begin{array}{l}\text { 1. Menjelaskan berbagai } \\
\text { kegiatan manusia yang } \\
\text { dapat mempengaruhi } \\
\text { kestabilan ekosistem, } \\
\text { misalnya penggunaan } \\
\text { bahan kimia dan } \\
\text { penebangan hutan. } \\
\text { 2. Meramalkan pengaruh } \\
\text { penggunaan bahan } \\
\text { kimia pada lingkungan } \\
\text { melalui pengamatan, } \\
\text { misalnya penggunaan } \\
\text { pupuk dan pestisida } \\
\text { secara berlebihan. }\end{array}$ & $\begin{array}{l}\text { Tugas } \\
\text { Kelompok }\end{array}$ & $\begin{array}{l}\text { Laporan } \\
\text { Hasil } \\
\text { diskusi }\end{array}$ & $\begin{array}{l}\text { 1. Jelaskan berbagai } \\
\text { kegiatan manusia yang } \\
\text { dapat mempengaruhi } \\
\text { kestabilan ekosistem, } \\
\text { misalnya penggunaan } \\
\text { bahan kimia dan } \\
\text { penebangan hutan. } \\
\text { 2. Jelaskan pengaruh } \\
\text { penggunaan bahan } \\
\text { kimia pada lingkungan } \\
\text { melalui pengamatan, } \\
\text { misalnya penggunaan } \\
\text { pupuk dan pestisida } \\
\text { secara berlebihan. }\end{array}$ \\
\hline
\end{tabular}


FORMAT PENILAIAN

PRODUK ( HASIL DISKUSI)

\begin{tabular}{|l|l|l|l|}
\hline No. & Aspek & Kriteria & Skor \\
\hline 1. & Konsep & * semua benar & 4 \\
& & * sebagian besar benar & 3 \\
& & * sebagian kecil benar & 2 \\
& & $*$ semua salah & 1 \\
\hline
\end{tabular}

\section{PERFORMANSI}

\begin{tabular}{|l|l|l|l|}
\hline No. & Aspek & Kriteria & Skor \\
\hline 1. & Pengetahuan & $*$ Pengetahuan & 4 \\
& & * kadang-kadang Pengetahuan & 2 \\
& & $*$ tidak Pengetahuan & 1 \\
2. & \multirow{3}{*}{ Praktek } & * aktif Praktek & 4 \\
& & * kadang-kadang aktif & 2 \\
3. & Sikap & * tidak aktif & 1 \\
& & $*$ Sikap & 4 \\
& & $*$ kadang-kadang Sikap & 2 \\
\hline
\end{tabular}

LEMBAR PENILAIAN

\begin{tabular}{|l|l|l|l|l|l|l|l|}
\hline No & Nama & \multicolumn{2}{|l|}{ Performan } & Produk & $\begin{array}{l}\text { Jumlah } \\
\text { Skor }\end{array}$ & Nilai \\
\cline { 3 - 7 } & Siswa & Pengetahuan & Praktek & Sikap & & & \\
\hline 1. & & & & & & & \\
3. & & & & & & & \\
4. & & & & & & & \\
5. & & & & & & & \\
\hline
\end{tabular}

\section{CATATAN :}

Nilai $=($ Jumlah skor $:$ jumlah skor maksimal $) X 10$.

Untuk siswa yang tidak memenuhi syarat penilaian KKM maka diadakan Remedial.

Mengetahui

Kepala Sekolah

Guru Mapel IPA

NIP :

NIP : 
BAHAN AJAR

$\begin{array}{ll}\text { Mata Pelajaran } & : \text { IPA } \\ \text { Kelas } & : \text { VI } \\ \text { Semester } & : \text { I }\end{array}$

I. Standar Kompetensi

3. Memahami pengaruh kegiatan manusia terhadap keseimbangan lingkungan

II. Kompetensi Dasar

3.1 Mengidentifikasi kegiatan manusia yang dapat mempengaruhi keseimbangan alam (ekosistem)

3.2 Mengidentifikasi bagian tumbuhan yang sering dimanfaatkan manusia yang mengarah pada ketidakseimbangan lingkungan

1. Bayani

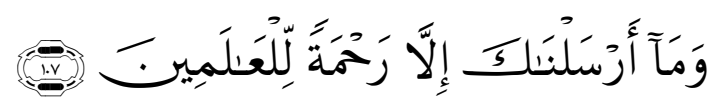

"dan Tiadalah Kami mengutus kamu, melainkan untuk (menjadi) rahmat bagi semesta alam”. (al-Anbiyaa: 107)

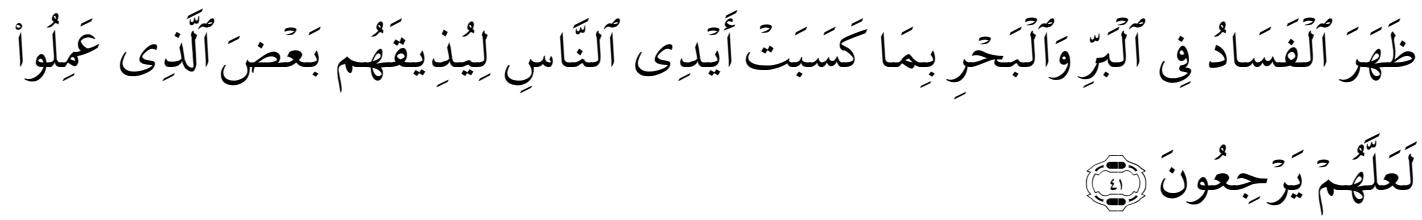

"Telah nampak kerusakan di darat dan di laut disebabkan karena perbuatan tangan manusia, supaya Allah merasakan kepada mereka sebahagian dari (akibat) perbuatan mereka, agar mereka kembali (ke jalan yang benar)". (al-Rum: 41)

2. Burhani

Dari keterangan surat al-Anbiya ayat 107 dan surat al-Rum ayat 41 menjelaskan tentang nampaknya kerusakan alam semesta ini dipengaruhi oleh beberapa faktor. Salah satu faktornya adalah manusia (khalifah) yang ada di bumi ini. Ada beberapa tumbuhan di bumi ini yang mempunyai manfaat untuk semua alam. Salah satu contoh tumbuhan yang terdapat diligkungan sekitar adalah tumbuhan jati. Tumbuhan jati atau pohon jati adalah pohon yang dapat tumbuh dengan baik di Indonesia. Dalam pemanfaatan sumber daya alam seperti tumbuhan jati nampaknya kurang terkontrol sehingga antara penanaman dan penebangan tidak sepadan. Sehingga menimbulkan beberapa masalah alam yang mengakibatkan 
bencana alam seperti tanah longsor, banjir, serta yang sedang gencar terdengar ditelinga masyarakat yaitu global warming.

3. Irfani

Daun jati dimanfaatkan secara tradisional di Jawa sebagai pembungkus makanan.nasi yang dibungkus dengan daun jati tersa lebih nikmat. Di Jawa Timur, masyarakat Pulau Bawean menyeduh daun jati untuk menghasilkan pewarna coklat merah alami. Masyarakat Lamongan memilih menyeduh tumbukan daun mudanya. Sementara itu masyarakat Pulau Madura mencampurkan tumbukan daun jati dengan asam jawa. Pada masa itu pengidap penyakit kolerapun dianjurkan untuk meminum seduhkan kayu dan daun jati yang pahit sebagai penawar sakit. Manusia memanfaatkan kayu untuk dibuat perabot rumah tangga, sepeti meja, kursi, dan almari, juga untuk dibuat rumah, seperti kusen, jendela, pintu juga untuk kerangka rumah. Pada abad ke-17, tercatat jika masyarakat Sulawesi Selatan menggunakan akar jati sebagai penghasil pewarna kuning dan kuning coklat alami untuk bahan anyaman.

\section{SIMPULAN}

Penulis menyimpulakan, bahwasanya Allah menciptakan semua yang ada dimuka bumi ini bukan dalam keadaan sia-sia. Pohon jati merupakan pohon primadona di Indonesia, selain pohon jati mempunyai manfaat dari akar hingga daunnya pohon jati juga berpengaruh dalam sistem ekologi di muka bumi ini. Hanya saja manusia dengan mengatas namakan kepentingan ekonomi dan kepentingan pribadi. Sering melakukan penebangan hutan secara liar serta tanpa melakukan reboisasi, hal itu secara langsung akan berdampak pada lingkungan hidup. Sudah saatnya kita sebagai khalifah dimuka bumi ini menyadari arti penting keseimbangan alam. Seperti yang telah diperintahkan Allah dalam surat al-Ambya dan al-Rum.

Melihat hal tersebut sebaiknya pembelajaran sains di madrasah ibtidaiyah seharusnya menanamkan nilai-nilai moral yang mendidik peserta didik menjadi berkarakter, hal tersebut dapat dilakukan salah satunya dengan memberikan pembelajaran sains menggunakan pendekatan integrasi bayani, burhani, dan irfani. 


\section{DAFTAR PUSTAKA}

Abdullah, Amin. (2007). Islamic Studies di Perguruan Tinggi. Yogyakarta: Pustaka Pelajar.

Abtokhi, Ahmad. (2008). Sains untuk PGMI dan PGSD. Malang: UIN Malang Press.

Alim, Sahirul. (1996). Menguak Keterpaduan Sains dan Teknologi. Yogyakarta: Titian Illahi Press.

Haryanto. (2007). Sains untuk Sekolah Dasar Kelas. Jakarta: Erlangga.

Hastuti, Wiwik Dwi, dkk. (2008). Perkembangan Peserta Didik, Edisi Pertama, Paket 1-7. Surabaya: Learning Assistance Program for Islamic Schools (LAPIS) PGMI.

Ismail, S.M. (2001). Paradigma Pendidikan Islam. Yogyakarta: Pustaka Pelajar.

Muqowim. (2012). Genealogi Intlektual Saintis Muslim Sebuah Kajian Tentang Pola Pengembangan Sains Dalam Islam Periode Abbassiyah. Jakarta: Balitbang Kementrian Agama RI.

Siregar, Nasyaria. (2013). Pengembangan Sains dalam Islam. Makalah dipresentasikan di Yogyakarta.

Sulistiyanto, H \& Wiyono, E. (2008). Ilmu Pengetahuan Alam untuk SD dan MI kelas V. Jakarta: Pusat Perbukuan Departemen Pendidikan Nasional.

Utami, D.T., dkk. (2006). Portofolio Pengetahuan Alam untuk Sekolah Dasar Jilid V. Jakarta: Erlangga. 